\title{
Austria
}

\section{Austria's agri-biotechnology regulation: political consensus despite divergent concepts of precaution}

\author{
Helge Torgersen and Alexander Bogner
}

The invocation of the precautionary principle, for instance, to prohibit the commercialisation of genetically modified crops in Austria, has been criticised for blurring the boundaries between science and politics. Three different understandings of precaution arise in the policy process around this case, and in the relevant actors' view of precaution and the perceived relationship between science and politics. The dominant 'political-economic' understanding has emphasised uncertainty about benefits and thus effectively reversed the burden of evidence. This was done without overtly shifting or challenging the boundary between science and politics, though their relative priority was reversed. The Austrian policy offers a pragmatic means to gain room for manoeuvre, rather than a coherent approach for a more reflexive way to deal with a controversial technology.

Helge Torgersen and Alexander Bogner are at the Institute of Technology Assessment, Austrian Academy of Sciences, Strohgasse 45, A-1030 Vienna, Austria; Tel: +43 151581 6588; Fax: +43 171098 83; Email: torg@oeaw.ac.at, abogner@ oeaw. ac.at; Website: http://www.oeaw.ac.at/ita/.

This paper arises from a research project, 'Precautionary Expertise for GM Crops' (PEG), funded by the European Commission, Quality of Life programme, socio-economic aspects, during 2002-2004 (contract no QLG7-2001-00034).
A MUCH-DISPUTED POLICY TOOL, the precautionary principle (PP) has only rarely been invoked in an explicit form in official policy. In particular, the Austrian Government rejected the European Union (EU) regulatory approval of three genetically modified (GM) maize varieties. Thus, Austria officially spearheaded the application of the PP on a national basis as a way to prevent the domestic use of GM varieties that already had been favourably assessed by other member countries' competent authorities (CAs). This formed part of the general Austrian policy on GM crops. As such, it can be taken as a case study for widening the scope of relevant arguments, resulting in a de facto reversal of the burden of evidence.

The application of the PP has been associated with blurring the boundary between science and policy from two sides. Scientists and regulators, advocating a 'sound science' approach in regulatory policy on risk issues, have criticised a politicisation of decision-making where only scientific risk arguments should count (Miller and Conko, 2001). On the other side, and from a theoretical point of view, authors developing the theory of reflexive modernisation regarded a boundary-blurring as an indication of a deep scepticism towards science (Beck et al, 2004).

After a brief history of GM policy in Austria, its application of the PP will be discussed in the light of this theory. We will then describe different understandings of precaution and their role in three GMrelated policy issues. In the conclusion, we will come back to the link drawn between the PP, the 
Helge Torgersen studied biology at the University of Salzburg, then worked as a researcher and lecturer at the Institute of Molecular Biology and the Institute of Biochemistry, University of Vienna. Since 1990, he has been a researcher at the Institute of Technology Assessment (ITA) of the Austrian Academy of Sciences. His main research interests are: comparative biotechnology policy and safety regulation; risk assessment of trangenic organisms and public perception of biotechnology; science studies in biotechnology; and methods of participatory technology assessment.

Alexander Bogner is researcher at the Institute of Technology Assessment (ITA) of the Austrian Academy of Sciences. $\mathrm{He}$ studied sociology at the University of Salzburg and Frankfurt am Main. His research interests include science and technology studies, bioethics and methods of empirical social research. His books on these topics include Wozu Experten? Ambivalenzen der Beziehung von Wissenschaft und Politik (with Helge Torgersen), Grenzpolitik der Experten and Das Experteninterview. His current project is a comparative study on bioethics commissions in Austria, Germany and UK.

reversal of the burden of evidence and the question of boundary blurring.

\section{Background: GM policy in Austria}

Over the mid- to late-1990s, strong nongovernmental organisation (NGO) campaigning and intense press coverage fuelled a sharp public debate on agricultural biotechnology. After some futile attempts at regulatory approval, no domestic release of a GMO has ever taken place (Mikl and Torgersen, 1996; Torgersen and Seifert, 2000), and no GM crop was ever legally grown. In contrast, basic research in biotechnology including plant technology saw a boost over the same period. Practical risk research, however, did not take off despite official promises in early 2000.

With risk assessment, the Austrian position has always been that agricultural practices, as a major determinant of environmental impacts, would have to be considered as an integral part. The organic farming sector in Austria was heavily subsidised, comprised a large proportion of farms, and was seen as a means to reconcile divergent demands from niche-market export strategy to protecting the rural structure, also with an eye to 'eco-tourism' (Mikl and Torgersen, 1996; Torgersen and Seifert, 2000).

Industry and science had to cope with this position. Long ago, industry limited its hopes for the development of the Austrian biotechnology sector to medical applications. Although this corresponded to the traditional weakness of the seed sector, the Austrian position was all the more remarkable if we take into account that a right-wing coalition came to power in 2000, with expectations of promoting agricultural biotechnology. However, the official Austrian position did not change significantly: cultivation and marketing of an AgrEvo maize variety containing a bacterial toxin gene (Bt) was banned in spring 2000.
Public controversy has been muted since 2000, in stark contrast to the years 1996-99. A likely reason was that Government policy simply left no room for NGO criticism, as it increasingly met every demand (apart from banning GMOs entirely). While in the public the non-GM option appeared as a matter of fact and even actors from industry and science began to embrace a non-GM future for Austria, Government officials were still divided. Although rarely in public, some of them considered GMOs to be worthwhile as a future option, if useful products were to become available. Similarly, until 2003, official farmer representatives would not declare themselves either against or for agricultural biotechnology; they tried to avoid the issue. They met fewer problems by aligning with the popular non-GM position of alternative farmers' associations.

\section{$P P$ and reflexive modernisation}

Beyond practical risk politics, the PP is also relevant for social theory observing the erosion of traditional relationships between science and society. For authors such as Ulrich Beck, precaution has significance for a general theory of modernisation. Accordingly, the PP indicates that "the assumption in favour of the innocence of scientific-technical progress increasingly becomes problematic" (Beck et al, 2001, page 73 [our translation]).

In such an understanding, the PP accommodates public demands to shift the burden of evidence in favour of more comprehensive risk prevention. It manifests the increasing scepticism towards science and challenges its priority in political decisions on risk. Precaution also becomes a lever for novel ideas of governance: as the experts' safety claims are challenged, claims of uncertainty are taken into account, the significance of unintended consequences is acknowledged, and non-scientific rationalities and actors from outside science have their say.

From a very different standpoint, this is close to what advocates of a 'sound science' approach in regulatory policy of risk issues often criticise. Both points of view agree in that precaution can be understood as blurring boundaries formerly held to be sacrosanct, such as the distinction between science and politics (or knowledge and values). However, and not surprisingly, they disagree over the interpretation.

The process of boundaries being transgressed or, in a narrower sense, becoming insignificant or irrelevant, that is, Entgrenzung (boundary blurring) is central to Beck's modernisation theory. The process can be described as signalling the dissolution or pluralisation of categorical distinctions (such as facts and values, knowledge and interests, nature and society, or life and death) that appeared natural in primary (industrial) modernity (Viehöver et al, 2004).

Boundaries are fundamental because they constitute resources for action, decision-making, and for assigning responsibilities (Viehöver, 2005). This is 
so not only in primary modernity but also in postmodern societies, in their process of secondary or reflexive modernisation. Accordingly, some boundaries are necessary (Beck et al, 2004): to regain the capacity to act and to assign responsibility, actors must constantly draw new boundaries.

Boundary-blurring and consequently boundarydrawing become interesting for the theory of modernisation because they provide criteria for empirical testing (which is not our intention here). A central argument is that modernity is reflexive from the moment when, as a consequence of scientific and technical developments, habitual boundaries and patterns of thinking are dissolved by means of risks and dangers released by (and in) the process of modernisation. From this point of view, the experts' boundary work is regarded as a sign of institutional dynamics (Bogner, 2005).

In this perspective, the PP indeed appears empirically amenable to the theory of reflexive modernisation in two ways: in contributing to the dissolution of boundaries, and in necessitating new boundaries under different contextual demands and thus indicating institutional change. However, such change is to be considered reflexive only if actors are aware of blurring boundaries formerly considered to be selfevident, and of their own effort to set up new boundaries. Hence, for 'reflexive modernisation', it is important not only how actors deal with the dissolution of boundaries but also how they perceive their role.

For that theoretical issue, the Austrian Government's precaution provides a test case by widening the scope of arguments considered relevant. Here we focus on the boundary between science and politics, as this coincides with a frequently raised criticism against broadening risk-assessment criteria.

In this case study, we investigated important actors' perception of precaution and of their role within a precautionary policy. We are aware that perceptions usually do not directly translate into politics. Nevertheless, they provide information about rationales and help to understand policy stances inviting diverging interpretations. We conducted a series of interviews with key experts,

\section{We investigated important actors' perception of precaution and of their role within a precautionary policy: although perceptions usually do not directly translate into politics, they provide information about rationales and help to understand policy stances inviting diverging interpretations}

regulators and NGO representatives. We also held three consecutive workshops with Government officials and experts involved in formulating the official Austrian position (Torgersen and Bogner, 2004). We asked whose interpretation of the PP became relevant, how actors saw the relationship between science and politics, and which decision criteria influenced policy, officially and unofficially.

\section{Understandings of precaution}

For the long-standing Austrian policy vis-à-vis GM crops, there seems to be a fairly unanimous interpretation among stakeholders, civil servants and scientists. This shared understanding extends to the de facto role of the PP as a political tool in routine administration. Interviewees from very different institutions saw the PP as a political contingency. They interpreted the handling of biotechnology, and GM maize in particular, as based on political considerations yet camouflaged with a scientific rationale. In such a view, boundaries between science and politics indeed seem to blur.

Actors seemed aware that this position is not only difficult to maintain within the European context, but also fragile on a domestic level. According to important domestic policy actors, Austrian policy was unique, marginal, and on the defensive in Europe. Even some responsible civil servants criticised a lack of co-ordination and the absence of an overall policy concept - strangely, because they could have developed one. In their view, politicians remain reluctant to deal with the issue, and strong forces (public opinion and NGOs) push policy away from what conventional science would suggest; so the boundary between science and politics, held to be 'natural', still existed unchallenged.

While pragmatic interpretations of political practice were largely overlapping, divergent normative views came to the fore when interviewees were asked about their interpretation of the PP as such. From statements made on different understandings of the PP, and taking into account different conceptualisations of uncertainty, we constructed three main understandings of precaution. These address the role of science, politics and public perception, and relationships among them.

Although there were many overlaps, scientists and civil servants from the Ministries of Research and of Trade tended to espouse a 'scientific' understanding. Those from the Ministry of Health (the competent authority), from the Federal Environment Agency (UBA, in charge of assessing proposals) and a member of the cabinet of the Minister of Agriculture argued along the lines of a political-economic understanding. NGO representatives and politicians from the Social Democrats and the Greens expressed views mostly in line with a 'normative' systemscritical understanding. 


\section{'Scientific' understanding}

Apart from a concession to public anxieties, aiming to achieve better acceptance, this understanding of the PP implies that uncertainty must be reduced by means of new knowledge, preferably through scientific investigation under the (precautionary) hypothesis of possible risk. What the risks are, and which consequences would be unacceptable, is determined in relation to the 'state-of-the-art' of modern technology and agriculture. In addition, the role of risk arguments in mobilisation campaigns is seen to foster public anxieties.

Dealing with uncertainty, and hence 'precaution', has always been a constituent of the scientific method involving case-to-case analysis and comparisons with established knowledge. The question of benefit is irrelevant, as extra knowledge already constitutes a benefit, or benefit is taken for granted within the existing system of exploiting scientific research results.

Hence, applying the PP implies more research, performed by those scientific disciplines that fulfil the criteria of (natural) science. Ethical aspects only play a role at a personal level and hence are scientifically irrelevant. Political decisions are rational, provided they are taken primarily on the basis of natural scientific insights. It is preferable, but not essential, for scientists to make decisions as long as they are taken on the basis of science. The boundary between science and politics is considered selfevident and strictly determined, but scientific arguments support specific political choices.

\section{'Political-economic' understanding}

In this understanding, the PP provides guidance in cases of decisions under uncertainty. Criteria are not only scientific but derive also from the expected distribution of risks and benefits, or from value judgements. They are therefore predominantly economic or ethical in character and need political backing. Science necessarily and admittedly produces uncertainty, so there is always residual uncertainty about possible risks. While risks from nature must be accepted, man-made risks can and should be minimised. However, the nature of the respective benefit is as important as (if not more important than) risk.

Therefore, the second main decision criterion is uncertainty about benefits. Hence at stake are less the health or environmental risks, as the Commission's interpretation of the PP might suggest, than uncertainty about compatibility with consensual socio-economic aims, for example, safeguarding small-scale and organic farming. Only uncertainty about health and environmental risks are internationally acknowledged to be relevant, so national authorities have to render instrumental the allpervasive cognitive uncertainty about such risks as a trigger for invoking the PP in practice. Although not considered to be in the driving seat, science is still seen to be separate from politics. Science delivers arguments that can be applied in a political struggle but loses its authority if politics interfere with scientific endeavours at finding the truth.

\section{'Normative' systems-critical understanding}

In this case, the PP opens up space for 'holistic' decisions, by taking into account non-quantifiable risks and long-term consequences, and by slowing down the decision-making process. The criteria for decisions derive from the relevant actors' normative orientations. There are two dominant critical orientations: first, environmental ethics based on a normative concept of Nature; and second, a 'modernisation'critical position against increasing economic disparities and (on a political level) the quasi-technological logic of de facto constraints. Here the PP is a kind of 'resistance principle' to be applied to benefit Nature, understood as being inherently wise, or to serve the protest against the democratic deficit or the monopolistic and all-engulfing capitalism in general by providing scientific arguments.

A benefit would be anything that promotes the political aim of a society oriented towards sustainability. Potential benefits of biotechnology, even if they could be framed according to this definition, are rejected because any such acknowledgement would weaken challenges to the present system. As with the previous understanding, to apply the PP is regarded as political, but less in the sense of being publicly accountable for risk-management judgements than in an instrumental sense. With regard to the distinction between science and politics, boundaries are weak but still exist. Science is supposed to serve political aims and is emphasised if politically necessary.

\section{Policy implications}

The three interpretations manifest different concepts of the relationship between science and politics, whereby each understanding of the PP is an example rather than the cause. Thus the PP frames the relationship in different ways; in addition, different political value judgements are involved.

For example, the first interpretation sees the Austrian commitment to organic agriculture as scientifically untenable, in other words, organic farming would not have anything to do with 'precaution'. The second understanding would conceptualise the benefit gained through both the use of less pesticides, and the socio-economic advantage of a niche-market saving farmers' livelihoods. The final understanding would see organic farming as the only tenable alternative, to be pursued on a general level. Thus, the boundary between science and politics plays a role only in the first interpretation, whereas it has little relevance in the other two.

The first and third understandings can be associated with established positions found elsewhere. 
Scientists and industry representatives, on the one hand, and (environmental) NGO activists, on the other hand, often describe precaution in similar terms. The political-economic understanding appears more peculiar and resonates strongly with the official Austrian position, in the sense that science should be "on tap" rather than "on top" (Stirling, 1999), without implying a weaker boundary between them. With this interpretation in mind, we now look at particular policy issues: risk-assessment strategies, stances on the de facto moratorium and the issue of GM-free areas.

\section{Risk assessment strategies}

From the very beginning of the debate on GM crops in Austria, officials advocated a broad concept of risk including the effects of agricultural practice. This could be interpreted as a shift in the boundary of a 'scientific' argument in risk assessment. In contrast, there was little risk research through scientific experimental releases.

In the official argumentation against particular product approvals, uncertainties arising from such risk assessments played an important role. Thus Austrian authorities followed a different track from other member states in assessing risks that had been underestimated or that had not been evaluated rigorously enough. In particular, Austria emphasised missing measurements of toxicological and allergenic effects especially of GM food products.

As a more novel aspect, Austria considered local conditions that might be different from those in other places, and that might suggest different solutions from an environmental point of view. Here, agricultural practice played a role as well; although the aim was to protect the environment, evaluations sometimes blurred the boundary between (what scientists would call) scientific and societal aspects.

Official risk assessors aimed to achieve an integrated, contextual appraisal, taking into account as many parameters as possible. This was no deliberate attempt to simply blur the boundary between science and politics. However, the integrated approach had the (perhaps not unintended) effect that assessments became more complicated, to the extent that decisions were made difficult if not impossible. This 'making things complicated' by taking into account aspects that could be considered both a risk and a socio-economic argument might have been a strategy to gain time or to preclude a pro-GM decision.

The Bt 11 maize case provides an example of how different arguments were applied to justify a national stance that was politically 'necessary'. Advocated by France under the Deliberate Release Directive, the application was criticised by several member states for its lack of detailed data, sloppy experimental design and the fact that it was submitted under the old regulatory framework. The Austrian position brought in additional dimensions: any GM product would have to wait until the problems of

\section{Conceptualising science as advising but not determining decisions allows values to be included separately, in an overall consideration of both values and scientific facts, as long as they are kept apart: science thereby can remain value-free and untainted by politics}

co-existence, cross-contamination and traceability could be solved at a European level. According to the Commission guidelines of July 2003, responsibility for co-existence measures remains at a national level (CEC, 2003), so harmonisation of the pertinent issues was likely to take considerable time, not only for cultivation uses but also for novel food.

Those advocating a "sound science" approach (Miller and Conko, 2001) often characterised such a position as being "unscientific", but this would not explain its rationale. Rather, it can be understood as a strategy to spare science the burden of taking political responsibility. Most interviewees, including regulators, viewed 'risk' as a social (or political) construct in which the role of science is relegated to providing advice.

The conceptualisation of science as advising but not determining decisions allows values to be included separately, in an overall consideration of both values and scientific facts, as long as they are kept apart. In an idealised understanding, science thereby can remain value-free and untainted by politics. This view is important for the question as to whether or not there was a blurring of the boundary between science and politics. In the dominant political-economic understanding, the boundary was still intact.

In fact, among institutional stakeholders and civil servants, risk assessment seemed to understand science as entirely independent, though its results must be subject to political deliberations. Scientific uncertainty is seen as inevitable and only to be managed through decisions that must be taken on a political basis, yet clearly indicated as such. Thus the Austrian understanding was seen as compatible with the separation of risk assessment and management in the Commission communication on the PP (CEC, 2000). However, current EU regulation would not allow acknowledging political decision-making as being legitimate in such a case. This conflict was understood as an inherent contradiction in the EU regulatory framework, rather than an oddity of the Austrian stance.

Although the Austrian position seemed fairly unique, some aspects of the 'political-economic' understanding were also compatible with Commission 
policy, given its functional separation between risk assessment and risk management. Although in practice the Commission often defers to official expert advice in the name of 'science', such a policy too implies a strategy to spare science the burden of taking political responsibility.

Likewise, the PP is allocated to a management decision, distinct from its scientific grounds (CEC, 2000). Thus, the Austrian 'political-economic' understanding of precaution could be seen as stretching the Commission's understanding rather than fundamentally diverging from it. Indeed, the dominant understanding's primary role was to interface with the EU regulatory system while reconciling it with political views among the Austrian public.

However, differences existed. For example, the Commission communication takes it for granted that there are different severities of risk, but it leaves open what type of risk would warrant applying the $\mathrm{PP}$, or what kind of unintended consequence would be deemed intolerable, for instance, to be called 'serious or irreversible harm'. In our workshops and interviews, emphasis was placed on general accounts of how to deal with any uncertainty about risks rather than on ranking risks that would be considered 'serious'.

The almost canonical list - of gene transfer, increased weediness, harm to non-target organisms, health hazards, and so on - would certainly be deemed 'serious', though sometimes for different reasons. The differentiation among types of harm was not always clear; for example, gene transfer was conceptualised as both an environmental hazard and an economic threat.

Often reference to 'benefits' appeared to be a way to avoid meticulous debates, obviously considered futile, about what risk would be severe enough to justify the application of the PP. Possible risks must be matched with 'benefits' - whatever they are and however they might be established. This was a prominent argument that recurred in different forms and gave rise to extended debates about 'other legitimate factors'. Thus, uncertainty about risk was no longer the decisive criterion, while uncertainty about benefit tended to take its place. In this way, and without seriously challenging the boundary between science and politics, Austrian procedures effectively reversed the burden of evidence.

\section{Interpretation of the de-facto moratorium}

By contrast to the Commission and some member countries that intended to lift the de facto moratorium, in summer 2003, Austria (together with other countries), officially proposed to maintain it. Thus the Austrian official position had not substantially changed since the late 1990s; on the contrary, a semi-official declaration in 2003 explicitly did not support the development and use of GM crops, at least for the foreseeable future. This position reflected a widespread consensus among the public,
NGOs, policy-makers and the agro-food sector, which had profited from being able to deliver guaranteed GM-free products.

The de facto moratorium was interpreted as a success for the Austrian position. It was an attempt "not to take any decision in the light of public hostility", as an interviewee from the Competent Authority stated, but also to gain more scientific insights, for example, ones that would support a more cautious approach to GMOs. Consequently, many policy actors considered the prolongation of the moratorium as desirable, for different reasons.

The revised Deliberate Release Directive was equally seen as influenced by Austrian ideas; it did not automatically ensure that new GM products would gain market approval, since it provided new criteria that could be applied in order not to grant permission. However, interviewees were often uncertain about the role of the revised Directive visà-vis other more 'vertical' regulation in force or pending, such as the GM Food and Feed Regulation, which they feared would marginalise environmental aspects and rather emphasise product properties.

Nevertheless, marketing authorisations under the revised Directive would still allow farmers to grow GMOs everywhere in the EU, more or less irrespective of local conditions (unless explicitly declared). Another major problem for Austria was the pending loss of its reputation as a source of GM-free products, because of possible contamination through gene flow. Thus the problem of contamination, at least in the political-economic understanding, became inevitably linked to the future of organic agriculture, which fitted better with the widespread anti-GM attitude in Austria. This link had been involved, often in the form of a strategic argument along the lines of the normative understanding, in the debate about biotechnology from the beginning. In the context of the search for 'benefits', market success for non-GM crops clearly would count as a benefit, especially if they were derived from environmentally friendly organic agriculture.

\section{GM-free areas}

Developments in the EU triggered political activity both at federal and regional level. In July 2002, a Parliamentary petition demanded zero tolerance with respect to GMO contamination. One means of ensuring the purity of organic and other GM-free produce was to establish identifiable, GM-free areas; hence, the petition proposed to declare the whole of Austria a 'GM-free region'. Originally this idea had arisen from the debate on the first application for a GMO release, as a basis for objection. A newspaper had taken up the idea and popularised it during the campaign for an anti-GM peoples' petition in 1997. The idea caught on through its simplified redefinition by the media, appealing to the general public attitude of Austria being an island. 
The debate about GM-free regions and/or coexistence, together with the July 2003 Commission proposal, led to an unprecedented consensus between government and opposition to strive for a GM-free agriculture, even at a time when Austria had intense political conflicts in general. This consensus was very popular but obviously politically unfeasible since it was at odds with EU policy, which would not permit national laws banning GM crops.

Nevertheless, given the federal structure of agricultural regulations, several regions had been discussing and preparing draft laws aiming to establish officially 'GM-free areas', irrespective of party differences. Initially, they had only been in the form of a political declaration, but legal provisions followed in 2003 in two regions, Upper Austria in the north and Carinthia in the south.

The European Commission closely monitored local developments that sought to restrict alreadyapproved products. While the Commission rejected the approach by Upper Austria to issue an outright if temporary ban on GMOs, Carinthia was successful with a more moderate solution of a 'precaution law'. The law established bans in specially protected and ecologically sensitive areas such as nature reserves or Alpine regions. The law also required growers to apply for permission in advance to grow GM crops. It stipulated minimum safety distances between GM and non-GM crops to prevent gene flow, in a way that would make a GM-based agriculture difficult to impossible in the light of the small average size of Carinthian fields.

The European Commission was suspicious about whether this amounted to a ban 'through the back door', so it demanded some amendments. For example, the Commission restricted bans in ecologically sensitive and/or protected areas in order to maintain proportionality; a ban may only be issued if it is "also necessary for an authorisation on an EU-wide level". The Commission in principle accepted the draft law in late 2003 and it was implemented in 2004. Meanwhile, several other Austrian regions followed suit.

Irrespective of some restrictions demanded, the Carinthian law set an EU-wide precedent, through political-administrative negotiation over stringent but flexible rules for co-existence. In addition, the possibility of setting up GM-free areas provided a reassuring rhetorical device. Problems remain, however, for example, in the definition and scope of what constitutes a GM-free area (whether it refers to the total absence of GMOs or relates to a certain species or product), of enforcement and of thresholds (as they are still inevitable for laboratory controls), and in the relationship between regions and the federal state in providing the infrastructure for controls.

For the co-existence issue, the authorities succeeded in circumventing the problem of whether or not a particular argument against GMOs is 'scientific'. Austria had a vanguard position in demanding measures to safeguard co-existence - for obvious reasons, as it appeared. In this way, Austrian regional authorities found solutions without having to defend themselves against attack for having applied 'unscientific' arguments. The shift in boundaries associated with such a step, however, remained largely implicit.

\section{Conclusion}

According to Beck, as long as the political system could not accommodate precautionary demands for risk prevention, it would face protests from the political periphery (Beck et al, 2001). Demands to reverse the burden of evidence would come from the bottom-up and would undermine the centre of the political system. In the Austrian case, however, impetus to apply the PP came from the top down, as part of a long-standing policy.

Precaution served to justify decisions rooted in the early days of biotechnology policy in Austria, influenced by largely consensual political considerations about socio-economic benefits. This particular position led the Austrian Government to apply the PP, rather than take a deliberate step towards reflexivity. Domestically, the Austrian CA was not forced to justify its judgements on scientific grounds, because it followed a popular, though tacit, political consensus on taking into account socio-economic benefits. However, in the EU, socio-economic arguments were not considered a valid criterion for regulatory decisions.

The Austrian stance reconciled seemingly mutually exclusive lines of argumentation, through a series of steps. First, the demand to take into account agricultural practice challenged the position of laboratory science, in favour of alternative knowledge (Torgersen, 1996). Secondly, invoking the PP emphasised uncertainty instead of scientifically proven effects. A third step effectively reversed the burden of evidence. Formerly, benefit was taken for granted and the decisive question was about risk. In the Austrian policy, uncertainty over risk is taken for granted and the decisive question is uncertainty over benefit.

All this was done without overtly shifting or challenging the boundary between science and politics, though their relative priority was reversed. The three understandings of precaution can illuminate that reversal. While science takes priority in the 'scientific' understanding, it supports political decisionmaking in the 'political-economic' understanding and is subject to strategic considerations in the 'normative' systems-critical understanding. The dominant 'political-economic' understanding showed its practical impact in all three examples of GMpolitical issues above.

Invoking the PP appears, in retrospect, to be a rational means to gain room for manoeuvre in a politically difficult situation under a contested scientific 
uncertainty. The Austrian stance has contributed policy elements compatible with a more 'reflexive' policy: comparative assessment of agricultural practices, long-term monitoring, and traceability including labelling. There is indication of such institutional change beyond Austria, even if most EU member countries considered the Austrian application of the PP still inappropriate.

Coming back to our theoretical point of departure, we can ask: what change occurred in the relationship between science and policy in this case? Boundaries between science and politics were blurred, though more implicitly in political practice than in the view of policy actors. For example, the relevant uncertainty was reframed around benefit rather than risk. From an epistemic point of view, however, policy actors did not overtly shift or disagree about boundaries between political versus scientific arguments. Rather, through the emphasis on uncertainty, political (or socio-economic) arguments gained a similar importance to scientific arguments, with both remaining firmly within their semantic categories.

Relevant actors seemed hardly aware of boundary-blurring; neither did they embrace the notion of multiple boundaries being equally legitimate, nor that of reflexively steering the process. The Austrian policy thus can be interpreted as offering a pragmatic means to gain room for manoeuvre, rather than as a coherent approach for a more reflexive way to deal with a controversial technology.

\section{References}

Beck, U, W Bonß and C Lau (2004) "Entgrenzung erzwingt Entscheidung: was ist neu an der Theorie reflexiver Modernisierung?", in Beck and Lau (2004), pages 13-62.
Beck, U, and C Lau (editors) (2004), Entgrenzung und Entscheidung: was ist neu an der theorie reflexiver Modernisierung? (Suhrkamp, Frankfurt/M).

Beck, U, B Holzer and A Kieserling (2001), "Nebenfolgen als Problem soziologischer Theoriebildung, in $U$ Beck and $W$ Bonß (editors), Die Modernisierung der Moderne (Suhrkamp, Frankfurt/M) pages 63-81.

Bogner, A (2005), "Experts' politics of drawing boundaries: dealing with non-knowledge and uncertainty in prenatal testing", Science, Technology and Innovation Studies, 1(1), available at $<$ www.sti-studies.de>, last accessed 17 August 2005.

CEC, Commission of the European Communities (2000), "Communication from the Commission on the precautionary principle" (Commission of the European Communities, Brussels).

CEC, Commission of the European Communities (2003), "Commission recommendation of 23 July on guidelines for the development of national strategies and best practices to ensure co-existence of GM Crops with conventional and organic farming" (Commission of the European Communities, Brussels).

Mikl, M, and H Torgersen (1996), "Austria's biotechnology regulation: from 'virtual releases' to public protest", Science and Public Policy, 23(3), June, pages 195-200.

Miller, H I, and G Conko ( 2001), "Precaution without principle", Nature Biotechnology, 19, pages 302-303.

Stirling, A (1999), On Science and Precaution in the Management of Technological Risk, EUR 19056/EN/2 (European Commission, Joint Research Centre, Brussels).

Torgersen, H (1996), "Ecological impacts of traditional plants - a basis for the assessment of transgenic plants?", UBA Monograph no 75, Federal Environment Agency, Wien.

Torgersen, H, and A Bogner (2004), Political Consensus Despite Divergent Concepts of Precaution national report on Austria for the project "Precautionary expertise for GM crops", Commission project number QLRT-2001-00034 (ITA, Wien) available at <www-tec.open.ac.uk/cts/peg/index.htm>, last accessed 17 August 2005.

Torgersen, H, and F Seifert (2000), "Precautionary blockage of agricultural biotechnology", Journal of Risk Research, 3(3), pages 209-217.

Viehöver, W (2005), "Der Experte als Platzhalter und Interpret moderner Mythen: das Beispiel der Stammzelldebatte", in A Bogner and $\mathrm{H}$ Torgersen (editors), Wozu Experten? Wissenschaft und Politik: Sozialwissenschaftliche Diagnosen einer Beziehung im Umbruch (Verlag für Sozialwissenschaften, Wiesbaden) pages 140-162.

Viehöver, W, R Gugutzer, R Keller and C Lau (2004) "Vergesellschaftung der Natur - Naturalisierung der Gesellschaft", in Beck and Lau (2004), pages 65-94. 